\title{
Improving the Objective Well Being of Productive Zakat Recipients by Applying Islamic Micro Finance at Baitul Mal Aceh, Indonesia
}

\author{
Alamsyah Alwi ${ }^{1}$ and Mutiara Dwi Sari ${ }^{2}$ \\ \{1alam.alwi@gmail.com ${ }^{1}, 2$ mutiara_dwisari@yahoo.com² ${ }^{2}$ \} \\ ${ }^{1}$ Faculty of Economy and Management, University College Bestari, Malaysia \\ ${ }^{2}$ Faculty of Social Sciences, University College Bestari, Malaysia
}

\begin{abstract}
This study aims to identify the level of objective well being of the productive zakat recipients in Baitul Mal Aceh Indonesia. The study was a descriptive quantitative that using average score to measure the level of objective well being. A total of 498 productive zakat recipients were involved in this study. The findings show that the level of objective well being of the productive zakat recipient is still moderate. Even for age groups 64 and above, the barber, and low educated respondents are still at low level of objective well being. Therefore, Baitul Mal Aceh needs to increase the amount of micro loans together with provide business expertise and management courses to enhance the bright future objective well being of productive zakat recipients.
\end{abstract}

Keywords: $\quad$ Objective well being, productive zakat

\section{Introduction}

The number of poor people in Indonesia increased from 27.76 million to 277.77 million. In the meantime, Aceh is the one of Province in Sumatera Indonesia which has the largest poverty index (BPS Indonesia, 2017). Before the earthquake and tsunami hit Aceh in 2004, the economic stages in Aceh were lower than in other parts of Indonesia due to war. (Cavallo and Noy, 2009) also point out that natural disasters and wars have a negative effect on the wellbeing of a nation's economy. Although Aceh has now received substantial financial allocations, the Aceh Government has yet to demonstrate its ability to solve poverty problems. Many government programs have not been able to address poverty and well being issues in Aceh (Wahyudi, Hamzah and Syahnur, 2014)(Rudi Wahyudi, Abubakar Hamzah, \& Sofyan Syahnur, 2014). Whereas, (Kataria, 2011) believed that poverty is the root of many social problems around the world. Hence, poverty in Aceh requires a more appropriate way of addressing its problems. (Ganguly, 2018), (Nagayya and Rao, 2017) and (Sani et al., 2017) believe that microfinance is effective in reducing poverty.

Unfortunately, most conventional microfinance still practices usury which is certainly not appropriate to practice in the Muslim community of (Hassan, 2010). In fact, Islam has tools that can be used to address poverty. (Kadri, Ahmad and Mohd Noor, 2012) states zakat is an Islamic fiscal policy tool that serves as a catalyst for economic development towards a high-income nation. In relation to microfinance, Baitul Mal Aceh has distributed productive zakat to micro entrepreneurs who have small businesses since 2006 (Riyaldi, 2015). According to (Abdullah, 2018) productive zakat is the property of zakat used to supporting business capital of the zakat recipients. While (Wahyuni, 2017) argued that productive zakat is a zakat fund that distributed to zakat recipients in an efficient and effective way with a versatile and productive system, in accordance with the message of shari'ah. 
Previously, (Armiadi, 2008) explains that the distribution of productive zakat aims to improve the economic well-being of the recipient. The majority of zakat productive recipients have successfully repaid their loan to Baitul Mal Aceh (Nurlaila and Hasnita, 2013). The question is, is it true that productive zakat has been proven to increase the objective well being of the recipients or the borrowers are simply able to repay their loan? Unfortunately, there are not many reports that explain the current state of the objective wellbeing of productive zakat recipients. Therefore, the purpose of this study is to analyze the level of overall objective wellbeing and to look at the level of objective well-being based on the demographic of the productive zakat recipient. The findings of this study are expected to be useful inputs to be used as a policy basis in improving the objective well being of the recipients of zakat and the people of Aceh.

\section{Literature Review}

(Dodge et al., 2012) states that well being is a new built concept. The effort to construct an acceptable well-being concept to the public is still difficult to do. (Frajman Ivković, Ham and Mijoč, 2014) provide an understanding of objective well-being as an achievement of sustainable economic development and reflecting in the state of material life. According to (Argyle, 2013), objective well being is a measurable and important variable for a good life. (Hayo and Seifert, 2003) also stated that objective well-being refers to something of a material nature.

Furthermore, experts also demonstrated the diversity of objective well being measurements(Estes and Sirgy, 2017) state that financial, occupation, education, health, leisure, sports, and recreation often get the attention of researchers. Meanwhile, (White, 2008) told the objective well-being could be measured by some of economic variables, nutrition, and health status. Furthermore, these indicators can also be transformed by measuring the perception or individual satisfaction level of each of these objective welfare indicators. But it cannot be denied that physical, material and life-standard necessities are basic in measuring prosperity. (Howell and Howell, 2008) explain that well being according to the theory of economic satisfaction can be achieved if an individual has income, wealth or savings, so he or she has the ability to buy that can make the increasing of consumption.

( $\mathrm{Ru}$ and $\mathrm{Lu}, 2002$ ) stated that the Chinese government had made basic food, clothing, housing, health and education costs as an indicator of the standard need to be given attention in maintaining the well being of its people. (Wu, 2013) also explains food, water, shelter, sufficient income and household assets is a basic human need that needs to be met for decent living. Meanwhile, (Streeten, 1979; Sugiharto, 2007; Mohd Shaladdin, Wan Abdul Aziz and Nik Wan, 2009), measure objective well being by looking at income, consumption, savings, the health of family members, the convenience of getting health services, the cost of a child's education per month, the value of the vehicle, the free time, and the frequency of recreation per month.

\section{Methodology}

Cross sectional study conducted in Aceh Province, Indonesia. Location selection is done by purposively. Aceh was chosen as the location of the study because it is the only Province in Indonesia running Islamic Sharia. Thus, Aceh has adopted more Islamic perspective development instruments such as productive zakat. After the 2004 Tsunami, Aceh received a large proportion of development funds but still had higher rates of poverty than other provinces in Sumatera. Productive zakat is chosen as an Islamic development instrument that 
is believed to potentially address the poverty problem in the area of which majority is Muslim. This study uses primary data obtained by questionnaire form. The study involved 498 beneficiaries of productive zakat in Aceh receiving loans from Baitul Mal Aceh since 2006. Data is analyzed by quantitative approach in order to look at the level of objective welfare according to the characteristic of the recipient of productive zakat on a demographic basis. Furthermore, the Statistical Package for Social Sciences (SPSS) Version 20 is used to measure objective well being with mean level indicators. The level of objective well being of zakat beneficiaries is measured by using five level of categories, where the average score of 1.00 1.49 is very low, average score of $1.50-2.49$ is low, average score of $2.50-3.49$ is moderate, average score of $3.50-4.49$ is high and average score of 4.50 - is very high.

Table 1. Overall Level Of Objective Well Being

\begin{tabular}{|c|c|c|c|c|}
\hline \multirow[b]{2}{*}{ No } & \multirow[b]{2}{*}{ Statement } & \multirow[b]{2}{*}{$\begin{array}{l}\text { Mini } \\
\text { mum } \\
\text { Score }\end{array}$} & \multicolumn{2}{|c|}{$\begin{array}{r}n=498 \\
\text { Mean }=2.83\end{array}$} \\
\hline & & & $\begin{array}{l}\text { Maxi } \\
\text { mum } \\
\text { Score }\end{array}$ & $\begin{array}{l}\text { Mean } \\
\text { Score }\end{array}$ \\
\hline \multicolumn{2}{|c|}{ Economic dimension } & & & 2.47 \\
\hline 1 & $\begin{array}{l}\text { Family income } \\
\text { per month }\end{array}$ & 1 & 5 & 2.91 \\
\hline 2 & $\begin{array}{l}\text { Family living } \\
\text { costs per month }\end{array}$ & 1 & 5 & 2.86 \\
\hline 3 & $\begin{array}{l}\text { Family savings } \\
\text { per month }\end{array}$ & 1 & 5 & 1.96 \\
\hline \multicolumn{2}{|c|}{$\begin{array}{l}\text { per month } \\
\text { House Dimensions }\end{array}$} & & & 3.41 \\
\hline 4 & $\begin{array}{l}\text { Home physical } \\
\text { condition }\end{array}$ & 2 & 4 & 3.29 \\
\hline 5 & $\begin{array}{l}\text { Facilities are at } \\
\text { home }\end{array}$ & 1 & 5 & 3.54 \\
\hline \multicolumn{2}{|c|}{ Health Dimensions } & & & 3.62 \\
\hline 6 & $\begin{array}{l}\text { Family health } \\
\text { level }\end{array}$ & 1 & 5 & 3.71 \\
\hline 7 & $\begin{array}{l}\text { The level of health } \\
\text { service facilities } \\
\text { obtained }\end{array}$ & 1 & 5 & 3.54 \\
\hline \multicolumn{2}{|c|}{ Educational Dimensions } & & & 2.56 \\
\hline 8 & $\begin{array}{l}\text { The cost of } \\
\text { schooling for } \\
\text { children per } \\
\text { month }\end{array}$ & 1 & 5 & 2.56 \\
\hline \multicolumn{2}{|c|}{ Vehicle Dimensions } & & & 3.65 \\
\hline 0 & $\begin{array}{l}\text { Value } \\
\text { of vehicles }\end{array}$ & 1 & 5 & 3.65 \\
\hline \multicolumn{2}{|c|}{ Time Dimension } & & & 1.71 \\
\hline 10 & $\begin{array}{l}\text { Time to relax per } \\
\text { day }\end{array}$ & 1 & 5 & 2.23 \\
\hline 11 & $\begin{array}{l}\text { Frequency of } \\
\text { recreation per } \\
\text { month }\end{array}$ & 1 & 5 & 1.19 \\
\hline
\end{tabular}

\section{Results And Discussions}

This section reports the level of objective well-being of productive zakat recipients in Baitul Mal Aceh either as a whole or according to respondents' demographics. There are six dimensions and 11 indicators shown. Table 1 shows the level of wellbeing of respondents' objectives as a whole. The economic dimension shows a low level of well-being (2.47). Respondent's income on average are at level 2.91. The respondents' income level was slightly thinner with the average cost of living (2.86), but both were still in the same group (moderate). Unfortunately, the level of family savings per month is still very low (1.96). On average, the dimensions of the home show a moderate situation (3.41). Although the level of facility 
indicator is high (3.54) but it is offset by a moderate physical condition (3.29). Health dimensions show high levels of health (3.62). Family health indicators (3.71) and access to health services (3.54) were high. The average level of children education expenditures is still moderate (2.56). On the dimensions of the vehicle, the indicator shows a high average level (3.65). Time dimension shows a low overall average level (1.71). The time to relax per day indicator is 2.23 and recreation 1.19 which is still low. However, the average level of overall well being of the respondents was relatively moderate (2.83).

Table 2 . Objective Well Being Based On Demographics

\begin{tabular}{|c|c|c|}
\hline & Demographic Items & $\begin{array}{l}\text { Level of Objective Well } \\
\text { being }\end{array}$ \\
\hline \multirow[t]{6}{*}{1} & Age: & \\
\hline & (25 years -34 year $)$ & 2.80 \\
\hline & (35 year -44 year ) & 2.79 \\
\hline & (45 year -54 year ) & 2.78 \\
\hline & $(55$ year -64 year $)$ & 2.99 \\
\hline & (64+ year) & 2.47 \\
\hline \multirow[t]{3}{*}{2} & Sex & \\
\hline & Women & 2.78 \\
\hline & Man & 2.87 \\
\hline \multirow[t]{12}{*}{3} & Business Type & \\
\hline & Food And Beverage & 2.77 \\
\hline & Mechanics & 2.86 \\
\hline & Fisherman & 2.68 \\
\hline & Retailers & 2.82 \\
\hline & Vegetable Sellers & 2.86 \\
\hline & Tailor & 2.78 \\
\hline & Farmers Vegetable & 2.61 \\
\hline & Breeders & 2.76 \\
\hline & Barber Shop & 2.18 \\
\hline & Stationary Shop & 3.36 \\
\hline & Laundry Shop & 3.09 \\
\hline \multirow[t]{7}{*}{4} & Education Level & \\
\hline & $\begin{array}{l}\text { Did Not Finish Primary } \\
\text { School }\end{array}$ & 2.04 \\
\hline & Finish Primary School & 2.64 \\
\hline & Junior High School & 2.66 \\
\hline & Senior High School & 2.90 \\
\hline & Diploma & 2.90 \\
\hline & Bachelor & 2.76 \\
\hline \multirow[t]{3}{*}{5} & Working Status of Spouse & \\
\hline & Not Working & 2.67 \\
\hline & Working & 2.85 \\
\hline \multirow[t]{3}{*}{6} & Marital Status & \\
\hline & Single & 2.58 \\
\hline & Married & 2.82 \\
\hline \multirow[t]{3}{*}{7} & Residence & \\
\hline & Rural & 2.88 \\
\hline & Urban & 2.75 \\
\hline
\end{tabular}

Table 2 shows the level of objective well being according to seven demographic variables: age, gender, business type, education level, working status of spouse, marital status and residence of recipient. In the age variable, the highest level of well being was present in the age group 55 years-64 years (2.99) which is still on moderate level of objective well being. Meanwhile, the lowest group was 64+ years old (2.47) and included in the low level of objective well-being. By gender, men have higher level of well being (2.87) than women (2.78). Both sexes are at moderate level. The business type that has the highest level of well being is the stationary shop (3.36) effort which is at moderate level. The level of objective well being of barber shop (2.18) is still in the low. Diploma holds the highest level of well 
being in the group of education (2.90) which is still a moderate level. The lowest level of objective well being in education is the respondents who did not finish their primary school (2.04) and is classified as a low level of objective well being. Respondents whose spouse also worked (2.85) had a higher level of objective well being than unemployed pair (2.67) but both are still at moderate level of objective well being. Respondents who have a partner (2.82) have a higher level of objective well being than those who do not have a partner (2.58). Both are still at moderate level of objective well being. The rural respondents (2.88) have higher level of objective well being than those who living in the city (2.75) and both are still at moderate level of objective well being. Overall, the level of objective well being was found to be moderate. This is influenced by the low level of time dimension and economic dimension which has low score min. It can suppress the excess of the objective well being level scores on other dimensions. The majority, the beneficiaries of zakat productive are small-scale entrepreneurs. Income from small daily sales is the cause of unable to employ a large number of employees. Employee wage would increase the cost of production and reduces business profits. To meet the number of employees, many productive zakat recipients have to involve their family members without being paid as employees. To address the shortage of workers, the recipient of productive zakat was forced to employ his own family members. The fact is also supported by (Mead and Liedholm, 1998) which states that most micro entrepreneurs in developing countries are involving their family members to save on production costs.

Family involvement can sometimes not be able to increase the amount of business output because some family members also lack the expertise and are not trained to perform the required work. Therefore, the recipient of productive zakat is forced to increase his working hours to complete his work. Moreover, if there are multiple orders from customers, they will reduce the time to rest. This causes the time dimension to be lower than other dimensions. Similarly, (Costa, 2003) found that most workers in developing countries are forced to work longer.

The shortage of skilled workers has been forcing to increase the number of working hours. This could also affect production quality. Many end products are damaged due to failure in the production process involving certain precision and expertise. The monitoring process of each stage of production is also not feasible. The damaged goods cause entrepreneurial losses (Billick, 2002). This situation is then a source of income. Furthermore, the cost of living has only led to a small of saving. This is supported by the findings of (Multifiah, 2007) which states that Baitul Mal is only able to lend a small amount of loan so it is less effective to increase the recipient's income.

Furthermore, the marketing of goods is still narrow and the method of marketing of goods is still following the traditional way without utilizing social media facilities, good advertising or the use of the latest conventional technology. Inadequate marketing, the absence of advertising and traditional marketing means would make difficult to increase the sales of goods produced. (Mulyana et al., 2014) also support this finding that micro entrepreneurs in Indonesia have only a little knowledge of marketing. The findings also show that the propensity to save the money is less than the propensity to buying goods and services. This situation is parallel with the theory of the marginal propensity to consume by (Keynes, 1936). In that theory it is clear that the characteristics of the lower class people is the percentage of their savings and the investment is smaller than the percentage of money they spend. That's because their income is more spent on buying the basic needs of his family. This proves that the recipients of productive zakat are still not categorized as a high level society but they are still is among the moderate society. 
According to demographic variables, the level of objective well being of zakat productive recipient also does not show a striking difference. Based on age, gender, type of business, education level, spouse's employment status, marital status and residence of the respondents on average still show a moderate level of well being. However, age variables in the 64 and above shows a low level of objective well being because older entrepreneurs are unable to work more to earn larger income. In addition, the limited number of employees, the small number of sales leads to a low level of objective well being for barbers. Very low levels of education also cause the level of well being become low. Low-educated respondents have lack of knowledge of how to grow their businesses.

\section{Conclusion}

This study was inspired by an issue of which the majority of the zakat productive recipients in Baitul Mal Aceh were able to repay their loans to Baitul Mal Aceh, but the effectiveness of productive zakat distribution on the objective well being has yet to be identified. Therefore, this study aims to identify the level of objective well being of productive zakat recipients in Baitul Mal Aceh Indonesia. Overall, the findings show that the objective well being of is still relatively moderate. Therefore, the productive zakat recipient should have the guidance of financial management and marketing of good goods and services. The provision of related courses should be given to the recipient of productive zakat and their family members who can potentially increase his family's income. In addition, Baitul Mal Aceh needs to increase the amount of productive zakat loans and increase the amount of zakat collection by promoting the awareness of paying zakat to the community. A large collection of zakat can help more productive zakat recipients in the future. The Aceh Kingdom is expected to be more active in creating new job opportunities for the Acehnese people. Such measures are more effective in expanding the business of the recipient of productive zakat after they are able to refund the loan from Baitul Mal Aceh. This is believed to have a positive effect on the enhancement of the future objective well being of the productive zakat recipient of Baitul Mal Aceh. The authors acknowledge with gratitude the support given by Universiti College Bestari to conduct research in the area of Islamic Management and Finance.

\section{References}

[1] Abdullah, A. (2018) 'STRATEGI PENDAYAGUNAAN ZAKAT PRODUKTIF Studi BAZ Kabupaten Sukabumi Jawa Barat', AL MASHLAHAH JURNAL HUKUM DAN PRANATA SOSIAL ISLAM STRATEGI, 5(3), pp. 1-14.

[2] Argyle, M. (2013) The psychology of happiness. United Kingdom: Routledge.

[3] Armiadi, A. (2008) Zakat Produktif: Solusi Alternatif Pemberdayaan Ekonomi Umat (Potret \& Praktek Baitul Mal Aceh). Banda Aceh: Ar-Raniry Press.

[4] Billick, I. (2002) 'The relationship between the distribution of worker sizes and new worker production in the ant Formica neorufibarbis', Oecologia, 132(2), pp. 244-249. doi: 10.1007/s00442-002-0976-7.

[5] Cavallo, E. A. and Noy, I. (2009) The Economics of Natural Disasters: A Survey, IDB WORKING PAPER SERIES. 124. doi: 10.2139/ssrn.1817217.

[6] Costa, G. (2003) 'Shift work and occupational medicine: an overview.', Occupational medicine (Oxford, England), 53(2), pp. 83-8. Available at: http://www.ncbi.nlm.nih.gov/pubmed/12637591 (Accessed: 11 January 2019).

[7] Dodge, R., Daly, A., Huyton, J. and Sanders, L. (2012) 'The challenge of defining wellbeing', International Journal of Wellbeing, 2(3), pp. 222-235. doi: 
10.5502/ijw.v2i3.4.

[8] Estes, R. J. and Sirgy, M. J. (2017) The Pursuit of Human Well-Being: The Untold Global History. Netherland: Springer Netherlands.

[9] Frajman Ivković, A., Ham, M. and Mijoč, J. (2014) 'Measuring Objective Well-Being and Sustainable Development Management Authors':, Journal of Knowledge Management, Economics and Information Technology, 4(2), pp. 1-29. Available at: www.scientificpapers.org.

[10] Ganguly, S. (2018) 'Micro-Finance and Poverty in India: A State-Level Analysis of Impact Assessment', in Ariwa, E., Coombs, H., El-Gohary, H., Jones, P., Ndubisi, N. O., Nwankwo, S., Packham, G., Saleh, Z., and Wonglimpiyarat, J. (eds) Financial Entrepreneurship for Economic Growth in Emerging Nations. India, pp. 194-216. doi: 10.4018/978-1-5225-2700-8.ch010.

[11] Hassan, M. K. (2010) 'N INTEGRATED POVERTY ALLEVIATION MODEL COMBINING ZAKAT, AWQAF AND MICRO-FINANC', in Seventh International Conference - The Tawhidi Epistemology: Zakat and Waqf Economy, pp. 261-281.

[12] Hayo, B. and Seifert, W. (2003) 'Subjective economic well-being in Eastern Europe', Journal of Economic Psychology, 24(3), pp. 329-348. doi: 10.1016/S01674870(02)00173-3.

[13] Howell, R. T. and Howell, C. J. (2008) 'The Relation of Economic Status to Subjective Well-Being in Developing Countries: A Meta-Analysis', Psychological Bulletin, 134(4), pp. 536-560. doi: 10.1037/0033-2909.134.4.536.

[14] Kadri, Z., Ahmad, S. and Mohd Noor, M. A. (2012) 'Zakat as A Catalyst to Economics Development: Towards High-Income Country', Persidangan Kebangsaan Ekonomi Malaysia ke VII (PERKEM VII) Transformasi Ekonomi dan Sosial Ke Arah Negara Maju, 2, pp. 1263-1273.

[15] Kataria, J. R. (2011) 'Poverty In South Asia: An Overview.', Interdisciplinary Journal of Contemporary Research in Business, 3(3), pp. 383-393.

[16] Keynes, J. M. (1936) General theory of employment, interest and money. United Kingdom: Palgrave Macmillan.

[17] Mead, D. C. and Liedholm, C. (1998) 'The dynamics of micro and small enterprises in developing countries', World Development, 26(1), pp. 61-74. doi: 10.1016/S0305750X(97)10010-9.

[18] Mohd Shaladdin, M., Wan Abdul Aziz, W. M. A. and Nik Wan, O. (2009) 'Analisis Kesejahteraan Hidup Nelayan Pesisir', Jurnal Kemanusiaan, 8, pp. 58-77.

[19] Multifiah, M. (2007) Peran ZIS Terhadap Kesejahteraan Rumah Tangga Miskin (Studi Penanggulangan Kemiskinan Melalui Bantuan Modal Pendidikan dan Kesehatan di Daerah Malang). Universitas Brawijaya.

[20] Mulyana, Y., Purwanti, Y., Patimah, S. and Susila, Y. (2014) Model Pengembangan Kompetensi Pemasaran Produk Rajut Dalam Meningkatkan Keunggulan Bersaing Ukm Rajut Binongjati Di Kota Bandung. Bandung: Lembaga Penelitian Universitas Pasundan.

[21] Nagayya, D. and Rao, D. K. (2017) 'Micro Finance and Support Organisations In the Southern States', Small Enterprises Development, Management \& Extension (Sedme) Journal, 36(4). Available

at: http://ojs.nimsme.org/index.php/Document1/article/view/395 (Accessed: 11 January 2019).1

[22] Nurlaila, N. and Hasnita, N. (2013) 'Tingkat Keberhasilan Program Pendayagunaan Zakat Produktif pada Baitul Mal Provinsi Aceh', SHARE, 2(2), pp. 170-187. 
[23] Riyaldi, M. H. (2015) 'Faktor-Faktor Yang Mempengaruhi Keberhasilan Penerima Zakat Produktif Baitul Mal Aceh: Satu Analisis', Jurnal Perspektif Ekonomi Darussalam, 1(2), pp. 185-202.

[24] Ru, X. and Lu, X. (2002) The Blue Book of Chinese Society 2002 (Zhongguo Shehui Lanpishu 2002). Beijing: Chinese Social Science Press (Zhongguo Sheke Chubanshe).

[25] Sani, A., Khan, M. S., Ahmed, H. R. N. and Aziz, B. (2017) 'Role of Micro Finance Institutions in Poverty Reduction', Imperial Journal of Interdisciplinary Research, 3(2), pp. 209-212. Available at: https://www.onlinejournal.in/IJIRV3I2/036.pdf.

[26] Streeten, P. (1979) 'From growth to basic needs.', Finance \& development, 16(3), pp. 28-31. Available at: http://www.ncbi.nlm.nih.gov/pubmed/12261287 (Accessed: 11 January 2019).

[27] Sugiharto, E. (2007) 'Tingkat Kesejahteraan Masyarakat Nelayan Desa Benua Baru Ilir Berdasarkan Indikator Badan Pusat Statistik', Epp, 4(2), pp. 32-36. doi: 10.1016/S0921-5093(99)00565-1.

[28] Wahyudi, R., Hamzah, A. and Syahnur, S. (2014) 'Analisis belanja pemerintah dan pertumbuhan ekonomi terhadap tingkat kemiskinan di aceh', Jurnal Ilmu Ekonomi, 2(3), pp. 49-59.

[29] Wahyuni, S. (2017) 'Peranan LAZ Sebagai Pengelola Zakat Dalam Pendayagunaan Zakat Produktif: Studi Kasus Rumah Zakat Medan', AT-TAFAHUM: Journal of Islamic Law, 1(2), pp. 104-125.

[30] White, S. C. (2008) But what is Wellbeing? A framework for analysis in social and development policy and practice, Regeneration and Wellbeing: Research into Practice.

[31] Wu, J. (2013) 'Landscape sustainability science: Ecosystem services and human wellbeing in changing landscapes', Landscape Ecology, 28(6), pp. 999-1023. doi: 10.1007/s10980-013-9894-9. 